\title{
An Assessment of Water Quality of Angaw River in South- eastern Coastal Plains of Ghana
}

\author{
A. Y. Karikari, ${ }^{1 *}$ J. K. Bernasko ${ }^{2}$ and E. K. A. Bosque-Hamilton ${ }^{1}$ \\ ${ }^{I}$ CSIR-Water Research Institute, P.O. Box M. 32, Accra, Ghana \\ ${ }^{2}$ AngloGold Ashanti, Obuasi, Ghana \\ *Corresponding author; E-mail: aykarikari@hotmail.com
}

\begin{abstract}
Physico-chemical and bacteriological water quality of the Angaw river were investigated at three different locations on the river. A range of water quality variables were measured in the river over a period of 12 months. The river was characterized by high ionic content. Relatively higher levels of ionic constituents occurred at the upstream while lower concentrations were observed downstream due to the influence of River Volta, which has lower ionic content. There was a dominance of $\mathrm{Na}$ and $\mathrm{Cl}$ over the cationic and anionic components, respectively, due to the effect of atmospheric deposition of sea salt. Calcium and magnesium showed a strong linear correlation $r=0.993$ significant at $p<0.05$, indicating biogeochemical mineral weathering. The water was moderately hard (mean range of $89-133 \mathrm{mgl}^{-1} \mathrm{CaCO}_{3}$ ), salty and neutral with mean $p \mathrm{H}$ of $7.3 \pm 0.13$. Conductivity, TDS and the major ions varied seasonally with elevated levels in the rainy season. However, nutrients levels were low during the study period and did not give any clear seasonal variation. The bacteriological quality of the water was poor, rendering it unsafe for domestic purposes without treatment. However, the water was suitable for primary and secondary contacts such as swimming and fishing. The poor bacteriological quality was due to direct contamination by animal and human wastes.
\end{abstract}

\section{Introduction}

Rivers are the most important freshwater resource for man. Social, economic and political development has been largely related to the availability and distribution of freshwaters contained in riverine systems. Water quality problems have intensified through the ages in response to the increased growth and concentration of populations and industrial centres. Polluted water is an important vehicle for the spread of diseases. In developing countries 1.8 million people, mostly children, die every year as a result of water-related diseases (WHO, 2004).

Ghana's water resources have been under increasing threat of pollution in recent years due to rapid demographic changes, which have coincided with the establishment of human settlements lacking appropriate sanitary infrastructure. This applies especially to peri-urban areas, which surround the larger metropolitan towns in the country. Many such settlements have developed with no proper water supply and sanitation services. People living in these areas, as well as downstream users, often utilise the contaminated surface water for drinking, recreation and irrigation, which creates a situation that poses a serious health risk to the people (Verma \& Srivastava, 1990).

The River Angaw runs through farmlands and rural communities before its confluence with River Volta. Not much studies have, however, been done on the water quality of the river. This would be of importance since water supply treatment was being planned to supply water to the entire community at the time of the study.

A number of factors influence water chemistry. Gibbs (1970) proposed that rock weathering, atmospheric precipitation, evaporation and crystallisation control the chemistry of surface water. The influence of geology on chemical water quality is widely recognised (Gibbs, 1970; Langmuir, 1997; Lester \& Birkett, 1999). The influence of soils on water quality is very complex and can be ascribed to the processes controlling the exchange of chemicals between the soil and water (Hesterberg, 1998). Apart from natural factors influencing water quality, human activities such as domestic and agricultural practices impact negatively on river water quality. It is, 
therefore, important to carry out water quality assessments for sustainable management of water bodies.

The study serves to determine the water quality of River Angaw. It provides the physicochemical and bacteriological characteristics of the water and, finally, contributes towards the limnological knowledge of the river.

\section{Study area}

\section{Materials and methods}

River Angaw is situated few kilometers from Ada Foah, a town noted for its beautiful beach and holiday resort (Fig. 1). The river is located between latitude $5^{\circ} 45^{\prime}-5^{\circ} 50^{\prime} \mathrm{N}$ and longitude $0^{\circ} 34^{\prime}-$ $0^{\circ} 38^{\prime}$ E. River Angaw follows a course of about $19.48 \mathrm{~km}$ to join the Volta Lake. There is virtually no industrial development in the area. Pollution within the area may come from human waste. The use of agro-chemicals is a potential problem, though the amounts in use are currently limited by high cost. The main economic activities in the catchment area are fishing, basket weaving and crop farming along the banks of the river. Major crops include vegetables, maize and cassava.

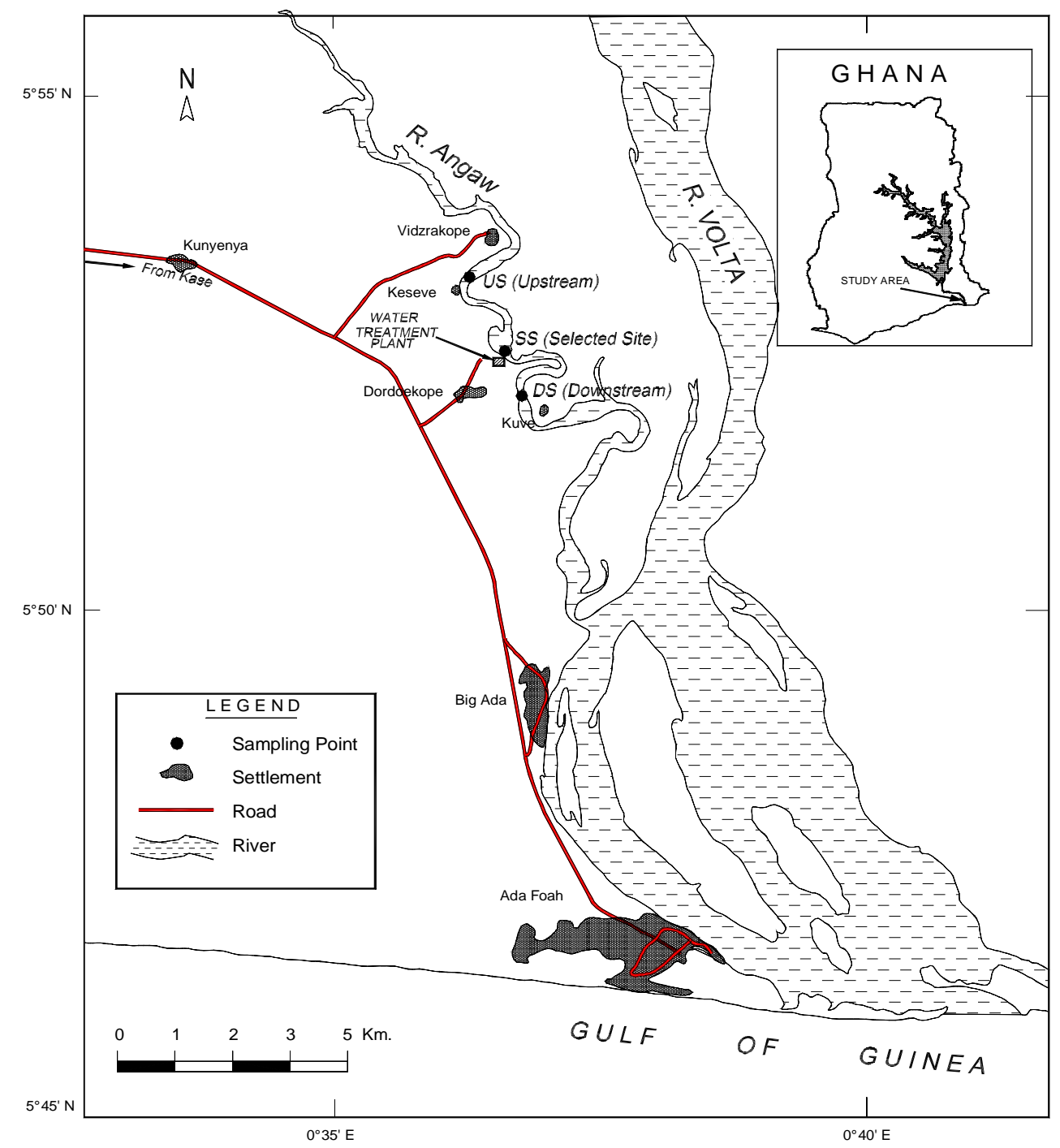


Fig. 1: Map showing the sampling points in the study area

The study area experiences two seasons; a dry season from November to March and a two maxima rainfall. According to data from the Ghana Meteorological Agency at the Ada synoptic station, the major rains occur between April and June with a break in July while the minor rains occur between August and October. Meteorological data (1994-2004) at the Ada synoptic station revealed that the annual rainfall for the study area was $796.3 \mathrm{~mm}$ with mean daily temperatures ranging between 25.9 in August and 30.0 in March.

\section{Sampling}

Three sites on River Angaw were selected and monitored once a month over a period of one year, from September 1997 to August 1998. The first site was located near the proposed water treatment plant known as selected site (SS) at Keseve. The other two sampling sites were located about $2 \mathrm{~km}$ upstream (US) and downstream (DS) of the proposed water supply treatment plant. Surface water samples for physico-chemical analyses were collected mid-stream at depth 20-30 $\mathrm{cm}$ directly into clean 1-litre plastic bottles. Temperature and $\mathrm{pH}$ were measured in situ, using a temperature probe and portable $p \mathrm{H}$ meter, respectively. For dissolved oxygen (DO) determinations, samples were collected into 300-ml plain glass bottles and the DO fixed using the azide modification of the Winkler's method. Samples for bacteriological analyses were collected into sterilized plain glass bottles. All samples were stored in an icebox and transported to the CSIR-Water Research Institute's Laboratory in Accra for analyses.

\section{Laboratory analyses}

The methods outlined in the Standard Methods for the Examination of Water and Wastewater (APHA, 1998) were followed for the analyses of all the physico-chemical parameters. Conductivity was measured with Jenway model 4020 conductivity meter, and turbidity with a Partech model DRT 100B Turbidimeter. Sodium and potassium were measured by flame emission photometry; calcium and magnesium by EDTA titration; sulphate by the turbidimetric method; colour by colour comparator and chloride by argentometric titration. Other analyses included alkalinity by strong acid titration method.

Nitrate-nitrogen was analysed by hydrazine reduction and spectrometric determination at 520 $\mathrm{nm}$, nitrite-nitrogen by diazotization and spectrophotometric determination at $540 \mathrm{~nm}$, phosphate by reaction with ammonium molybdate and ascorbic acid, and measured at $880 \mathrm{~nm}$, and ammonium by direct nesslerisation and spectrophotometric determination at $410 \mathrm{~nm}$. Fluoride by SPADNS method and total dissolved solids, and suspended solids were measured gravimetrically after drying in an oven to a constant weight at $105^{\circ} \mathrm{C}$. Total and faecal coliforms were determined by membrane filtration method using M-Endo-Agar Les (Difco) at $37^{\circ} \mathrm{C}$ and on MFC Agar at 44 ${ }^{\circ} \mathrm{C}$, respectively.

\section{Statistical analysis}

Pearson's rank correlation was used to establish relations between parameters. All tests were two-tailed. The analyses were executed by SPSS (version 12 for Windows, year 2003).

\section{Results and discussion}

The physico-chemical and bacteriological characteristics of River Angaw are presented in Tables 1and 2, and Fig. 2-4. 
Physical characteristics of Angaw river.

\begin{tabular}{|c|c|c|c|c|c|c|}
\hline \multirow[t]{2}{*}{ Parameter } & \multirow{2}{*}{$\begin{array}{l}\text { Upstream (US) } \\
\text { Mean } \pm S D\end{array}$} & \multicolumn{2}{|c|}{ Selected site $(S S)$} & \multicolumn{2}{|c|}{ Downstream $(D S)$} & \multirow[b]{2}{*}{ Range } \\
\hline & & Range & Mean $\pm S D$ & Range & Mean $\pm S D$ & \\
\hline Temperature $\left({ }^{\circ} \mathrm{C}\right)$ & $29.5 \pm 1.8$ & $26.0-33.5$ & $29.1 \pm 1.7$ & $26.8-32.6$ & $29.4 \pm 2.0$ & $26.4-33.8$ \\
\hline$p \mathrm{H}$ & $7.2 \pm 0.13$ & 7.0-7.4 & $7.3 \pm 0.09$ & $7.1-7.4$ & $7.3 \pm 0.11$ & $7.1-7.5$ \\
\hline Turbidity (NTU) & $2.96 \pm 1.3$ & $0.90-5.10$ & $2.28 \pm 1.2$ & $0.60-4.60$ & $1.75 \pm 0.87$ & $0.70-3.40$ \\
\hline Conductivity $(\mu \mathrm{S} / \mathrm{cm})$ & $947 \pm 194$ & $698-1222$ & $742 \pm 321$ & $412-1400$ & $608 \pm 394$ & 243-1306 \\
\hline $\operatorname{TDS}\left(\mathrm{mgl}^{-1}\right)$ & $603 \pm 155$ & $436-960$ & $474 \pm 173$ & $290-772$ & $376 \pm 210$ & $186-724$ \\
\hline $\mathrm{SS}\left(\mathrm{mgl}^{-1}\right)$ & $8.56 \pm 4.3$ & $3.00-18.0$ & $7.11 \pm 3.2$ & $2.00-10.0$ & $5.50 \pm 3.4$ & $1.00-9.00$ \\
\hline Total hardness $\left(\mathrm{mgl}^{-1}\right)$ & $133 \pm 20.6$ & $96.2-159$ & $107 \pm 28.0$ & $70.2-145$ & $89.0 \pm 40.2$ & $46.0-15$ \\
\hline Alkalinity $\left(\mathrm{mgl}^{-1}\right)$ & $43.1 \pm 3.1$ & $38.0-48.0$ & $40.6 \pm 2.7$ & $37.0-44.0$ & $35.8 \pm 4.7$ & $26.0-42.0$ \\
\hline $\mathrm{DO}\left(\mathrm{mgl}^{-1}\right)$ & $6.15 \pm 0.96$ & $5.00-7.80$ & $6.51 \pm 0.86$ & $5.30-8.70$ & $6.87 \pm 0.79$ & $6.00-8.50$ \\
\hline
\end{tabular}

TABLe 2

Nutrient concentrations of Angaw River in $\mathrm{mgl}^{-1}$

\begin{tabular}{|c|c|c|c|c|c|c|}
\hline \multirow[t]{2}{*}{ Parameter } & \multicolumn{2}{|c|}{ Upstream (US) } & \multicolumn{2}{|c|}{ Selected site (SS) } & \multicolumn{2}{|c|}{ Downstream (DS) } \\
\hline & $M e a n \pm S D$ & Range & Mean $\pm S D$ & Range & $M e a n \pm S D$ & Range \\
\hline Nitrate-N & $0.88 \pm 1.7$ & $0.14-6.1$ & $0.321 \pm 0.42$ & $0.005-1.5$ & $0.304 \pm 0.47$ & $0.005-1.7$ \\
\hline Phosphate-P & $0.030 \pm 0.05$ & $0.002-0.14$ & $0.05 \pm 0.12$ & $0.002-0.40$ & $0.030 \pm 0.05$ & $0.002-0.15$ \\
\hline Ammonia-N & $0.191 \pm 0.22$ & $0.005-0.55$ & $0.144 \pm 0.11$ & $0.005-0.28$ & $0.113 \pm 0.17$ & $0.005-0.50$ \\
\hline Silica & $14.2 \pm 3.2$ & 7.75-18.6 & $11.0 \pm 3.1$ & $5.64-14.3$ & $11.2 \pm 3.4$ & $4.50-14.6$ \\
\hline
\end{tabular}




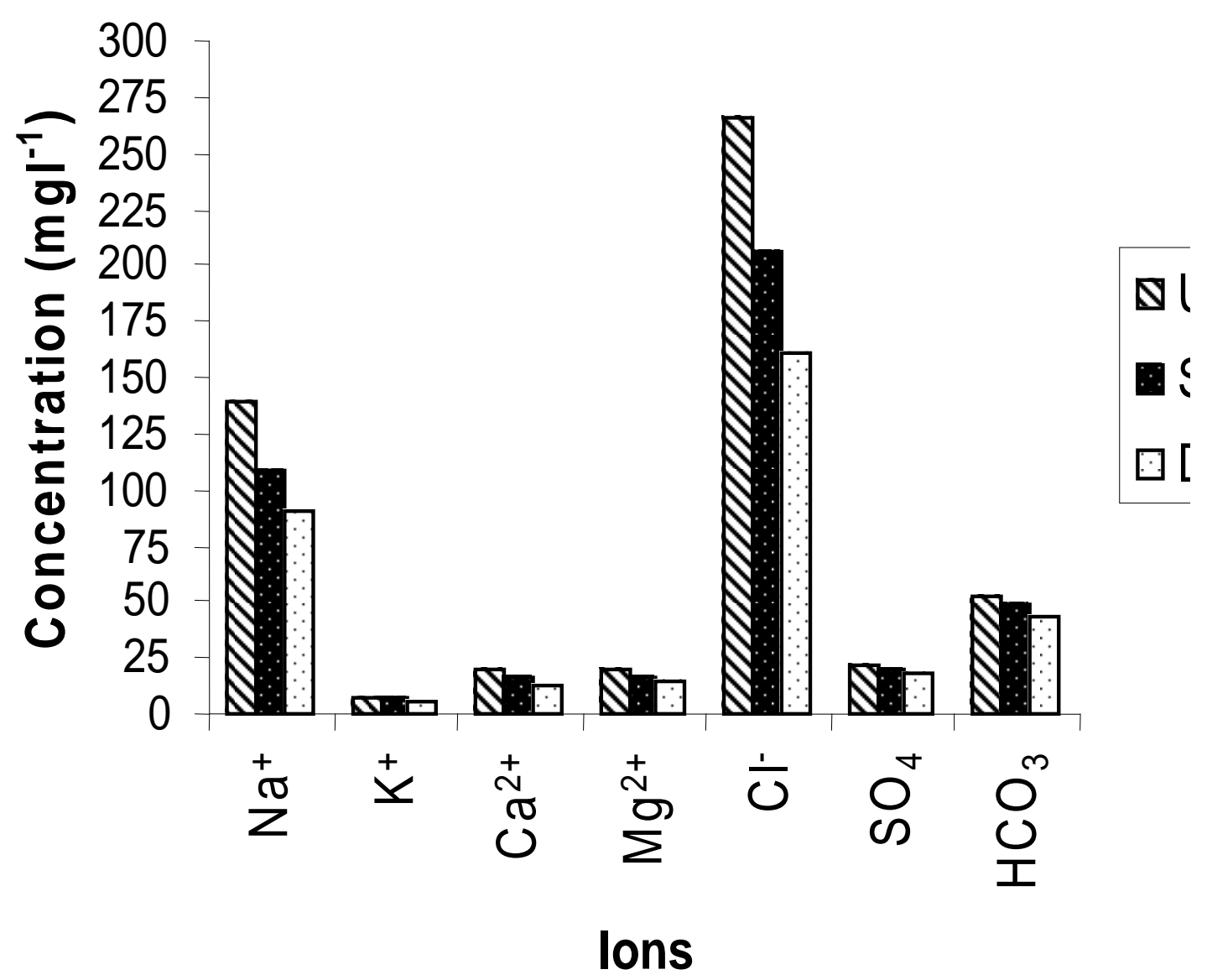

Fig. 2. Mean ionic concentrations of Angaw river 


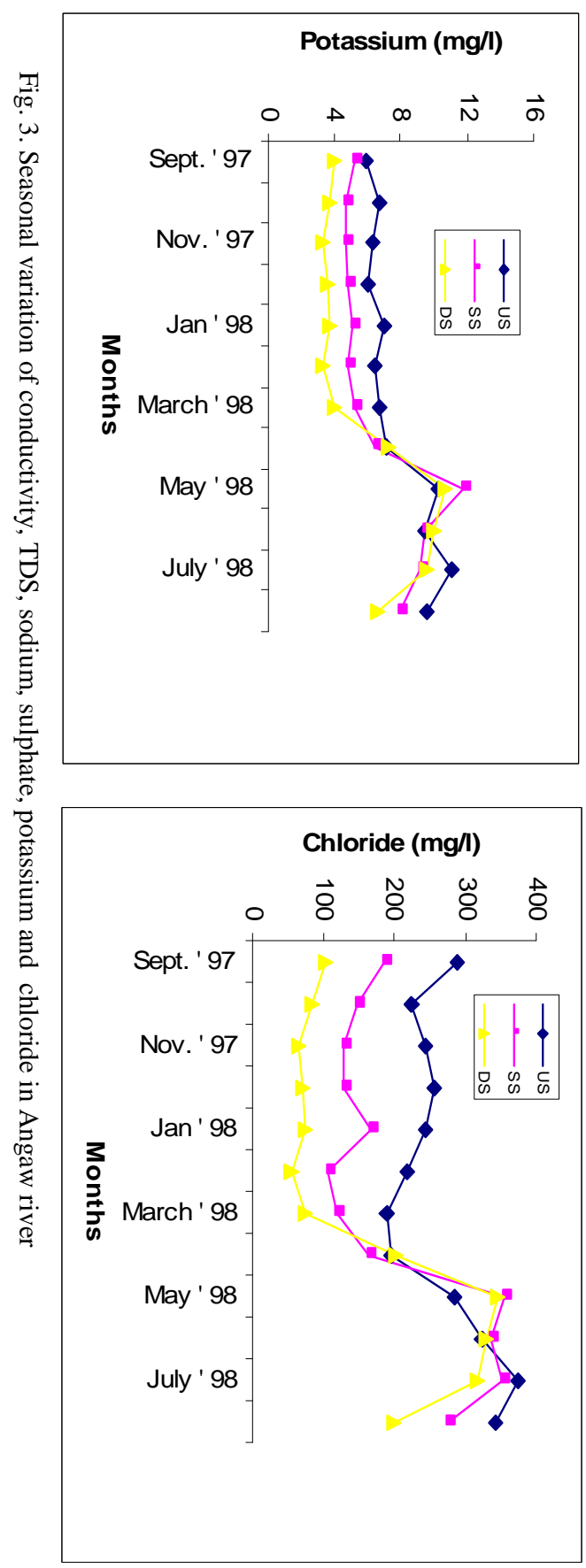

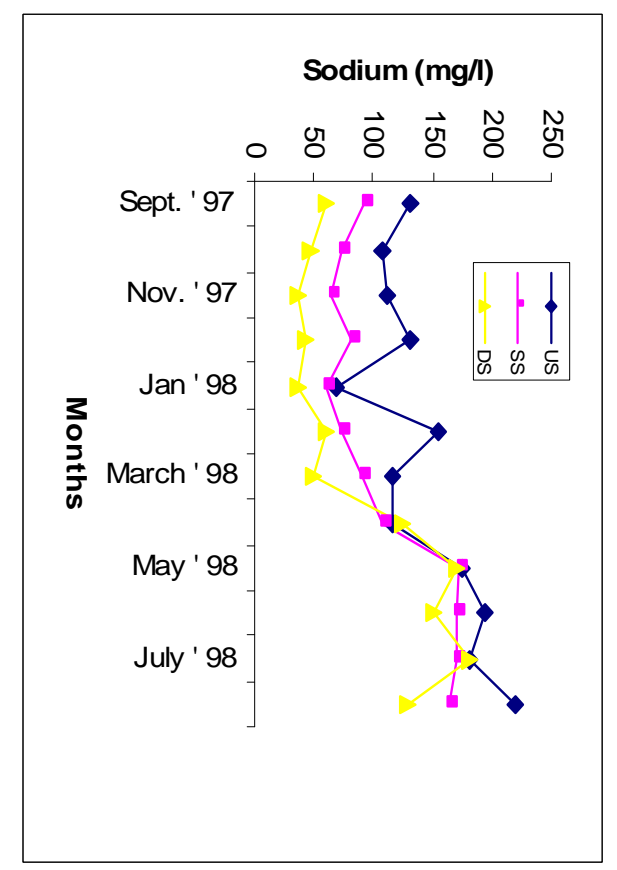

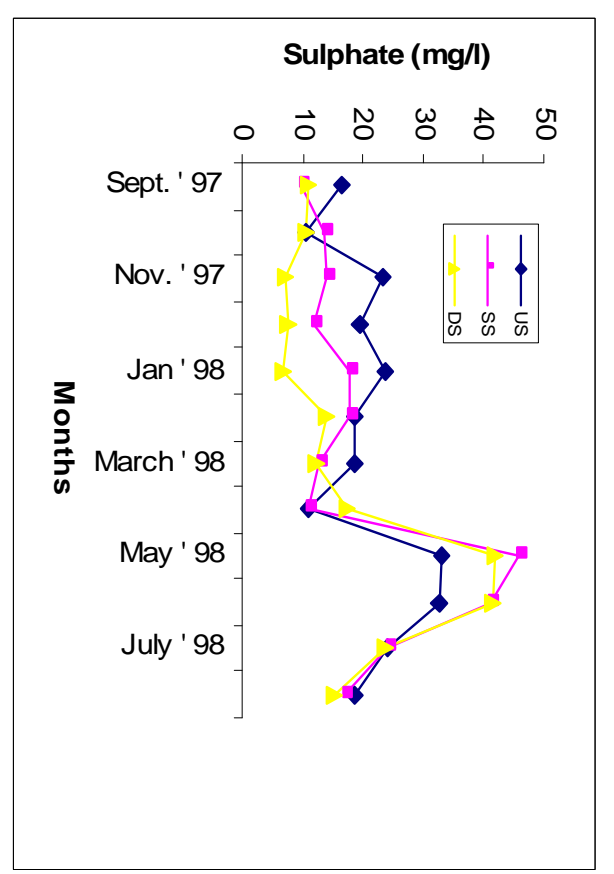

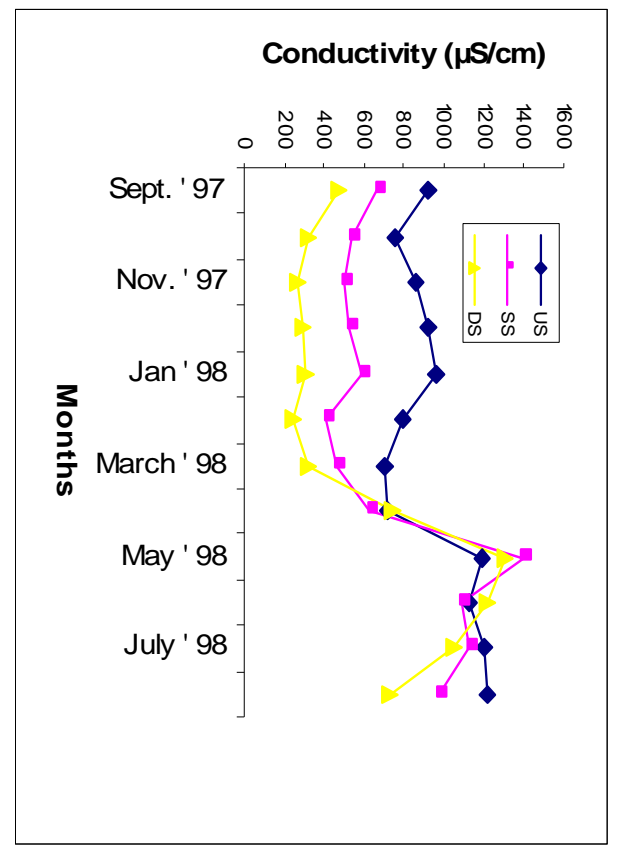

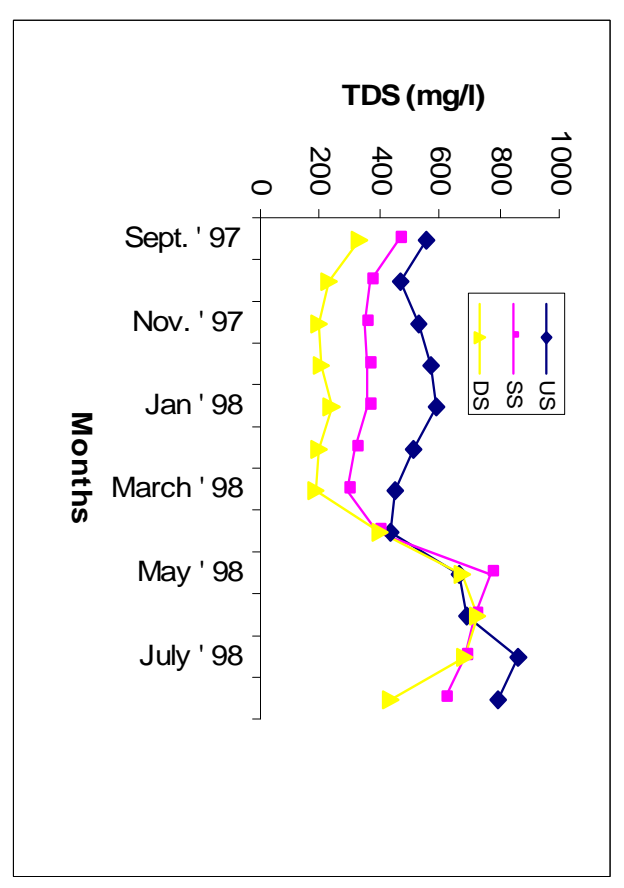




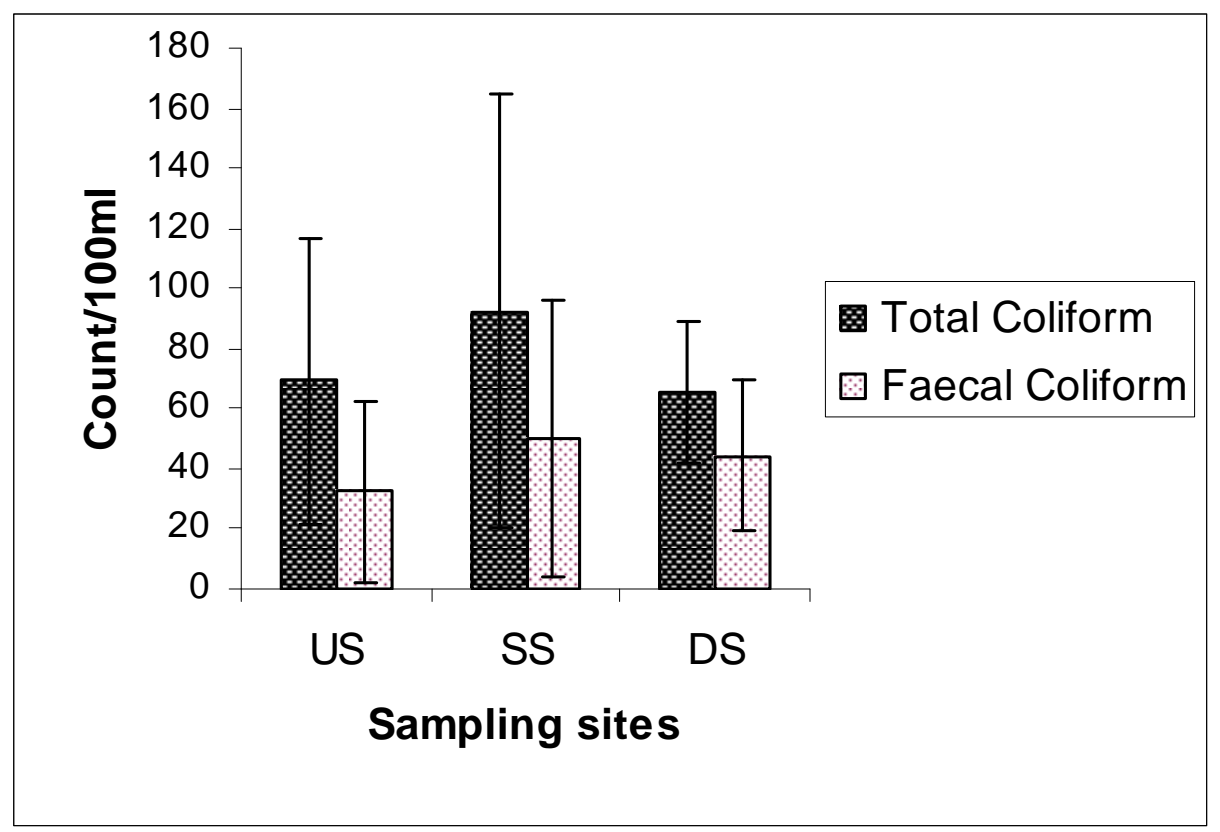

Fig. 4. Mean \pm SD total and faecal coliforms of upstream (US), selected site (SS) and downstream (DS) of Angaw River

\section{Physical characteristics}

The mean $p \mathrm{H}$ of the river water was neutral at all stations for the study period with a range of 7.2-7.3. The $p \mathrm{H}$ fell within the range associated with most natural waters which is between 6.0 and 8.5 (Chapman, 1992), stipulated for drinking and domestic purposes. The mean conductivity of the river ranged between 608 and $947 \mu \mathrm{S} / \mathrm{cm}$ in this order of increasing magnitude: downstream < selected site < upstream. This order prevailed most of the time throughout the study period. The downstream recorded relatively low conductivity throughout the monitoring, due to dilution from River Volta which has much lower conductivity $(62-77.5 \mu \mathrm{S} / \mathrm{cm}$ ) (Antwi \& Ofori-Danson, 1993). The upstream level was always high probably due to the nature of the soil at the water source.

Mean values of turbidity were 2.96 NTU, 2.28 NTU and 1.75 NTU for the upstream, selected site and downstream, respectively. The levels of turbidity recorded in this study were comparable to those reported for River Volta at Akuse (mean range 2.8-3.2 NTU) by Water Research Institute (1999). However, average turbidity recorded in Birim basin (37.5 NTU) by Ansa-Asare \& Asante (2000) were much higher than those observed in the study. The low turbidity throughout the sampling period suggests that discharges from domestic effluents and run-offs from agricultural activities that reach the river may be minimal or large particulates that readily settled to the bottom. The low turbidity of the river will facilitate water purification processes such as flocculation and filtration, which could reduce treatment cost.

The hardness of the river reduced from upstream to the downstream. The US, SS and DS recorded average hardness levels of 133, 107 and $89 \mathrm{mgl}^{-1} \mathrm{CaCO}_{3}$, respectively. The relatively lower levels downstream may be attributed to the influence of River Volta which has very low levels of hardness (19-38 $\mathrm{mgl}^{-1} \mathrm{CaCO}_{3}$ ) (Antwi \& Ofori-Danson, 1993). Alkalinity followed a similar trend as hardness.

Dissolved oxygen (DO) mean levels varied between 6.15 and $6.87 \mathrm{mgl}^{-1}$. The downstream had relatively higher oxygen throughout the study. This might be due to the windy nature of the area and the regular mixing of the water with the Volta Lake which has higher DO content. Pristine 
surface waters are normally saturated with DO, but such DO can be rapidly removed by oxygen demand of organic wastes. The measurement of DO provides a broad indicator of water quality (DFID, 1999). DO concentra-tions in unpolluted water are normally about $8.0-10 \mathrm{mg} / \mathrm{l}\left(\right.$ at $\left.25^{\circ} \mathrm{C}\right)$ (DFID, 1999). Concentrations below $5.0 \mathrm{mgl}^{1}$ adversely affect aquatic life. The concentration of DO in the Angaw river were above $5.0 \mathrm{mgl}^{-1}$ and, therefore, the river water would be suitable for use of the aquatic ecosystem.

\section{Nutrients}

$\mathrm{NH}_{4}-\mathrm{N}, \mathrm{NO}_{3}-\mathrm{N}$ and $\mathrm{NO}_{2}-\mathrm{N}$ are considered to be non-cumulative toxins (Dallas \& Day, 1993). High concentra-tions of $\mathrm{NO}_{3}-\mathrm{N}$ and $\mathrm{NO}_{2}-\mathrm{N}$ may give rise to potential health risks particularly in pregnant women and bottle-fed infants (Kempster et al., 1997; Kelter et al., 1997). $\mathrm{NO}_{3}-\mathrm{N}$ at elevated concentra-tions is known to result in cyanosis in infants. Ammonia is naturally present in surface water and groundwater and can be produced by the deamination of organic nitrogen containing compounds and by the hydrolysis of urea. The problem of taste and odour may, however, arise when the $\mathrm{NH}_{4}-\mathrm{N}$ level is greater than $2 \mathrm{mgl}^{-1}$. Above $10 \mathrm{mgl}^{-1}$, appreciable amounts of $\mathrm{NO}_{3}-\mathrm{N}$ may be produced from $\mathrm{NH}_{4}-\mathrm{N}$ under suitable anaerobic conditions (WHO, 1993; Kempster et al., 1997).

The mean concentrations of nutrients are presented in Table 2. Nitrate levels averaged 0.880 $\mathrm{mgl}^{-1}$ as $\mathrm{N}$ at the upstream; $0.321 \mathrm{mgl}^{-1}$ at the selected site and $0.304 \mathrm{mgl}^{-1}$ at the downstream. The average $\mathrm{NO}_{3}-\mathrm{N}$ concentration of Angaw river was much higher than the $0.1 \mathrm{mgl}^{-1}$ for unpolluted world rivers (Webb \& Walling, 1992). The WHO safe limit for nitrate for lifetime use is $10 \mathrm{mgl}^{-1}$ as $\mathrm{N}$ (WHO, 1984). This limit was not exceeded in the river water; thus, nitrate is not considered to pose a problem for the domestic use of water from the river. However, nitrate could be a problem for other uses because of eutrophication (Rast \& Thornton, 1996).

Mean levels of ammonia were $0.191 \mathrm{mgl}^{-1} ; 0.144 \mathrm{mgl}^{-1}$ and $0.113 \mathrm{mgl}^{-1}$ for upstream, selected site and downstream, respectively. Low ammonia concentrations were also observed in the Kpong Reservoir by Antwi \& Ofori-Danson (1993) with a mean of $0.02 \mathrm{mgl}^{-1}$ and a range of $<0.001-$ $0.12 \mathrm{mgl}^{-1}$. At Akuse on the Volta river, Water Research Institute (1999) recorded a mean level of $0.21 \mathrm{mgl}^{-1}$ ammonia and a range of $0.193-0.227 \mathrm{mgl}^{-1}$. Unpolluted waters contain small amounts of ammonia, usually less than $0.1 \mathrm{mgl}^{-1}$ (Chapman, 1992). The concentrations of ammonia in the Angaw river for the duration of the study were not alarming due to low anthropogenic activities reaching the river.

Phosphurous is the limiting nutrient for algal growth and, therefore, controls the primary productivity of a water body. In most natural surface waters, phosphorous ranges from 0.005 to $0.020 \mathrm{mgl}^{-1} \mathrm{PO}_{4}-\mathrm{P}$ (Chapman, 1992). In some pristine waters concentra-tions as low as 0.001 $\mathrm{mgl}-^{-1}$ may be found. Mean levels of phosphates were $0.030 \mathrm{mgl-}^{-1}$ as $\mathrm{P}$ at the US; 0.050 mgl- ${ }^{-1}$ at the SS; and $0.030 \mathrm{mgl}^{-1}$ at the DS. High concen-trations of phosphate can indicate the presence of pollution and are largely responsible for eutrophic conditions. Eutrophication-related problems in warm-water systems begin at $\mathrm{P}$ concentrations of the order $0.34-0.70 \mathrm{mg} \mathrm{P} / 1$ (Rast \& Thornton, 1996). The associated $\mathrm{N}$ concentrations would be of the order $0.34-0.70 \mathrm{mg} \mathrm{N} / \mathrm{l}$.

It is accepted that these represent nutrient threshold levels, beyond which there will be a corresponding increase in the risk and intensity of plant-related water quality problems (OECD, 1982). River Angaw was not observed to be eutrophic, nevertheless, care must be taken so that eutrophication would not be a problem in the river. The river is being abstracted and treated to supply water to Ada Foah, Kasseh and its environs and eutrophication could increase its treatment cost through filter clogging in water treatment works (Murray et al., 2000).

Silica is an essential element for aquatic plants (e.g. diatom). It is taken up during cell growth and released during decomposi-tion and decay giving rise to fluctuations. The mean silica values 
(between 11 and $14.2 \mathrm{mgl}^{-1}$ ) observed in the river (Table 2) was higher than the world average of $9 \mathrm{mgl}^{-1}$ in rivers (Horne \& Goldman, 1995) but fell within 1-30 $\mathrm{mgl}^{-1}$ which is the range for most rivers and lakes (Chapman, 1992).

\section{Major ions}

The concentrations of the major cations in the river were generally in the order of $\mathrm{Na}>\mathrm{Mg}>$ $\mathrm{Ca}>\mathrm{K}$. The major anion concentrations followed the order $\mathrm{Cl}>\mathrm{HCO}_{3}>\mathrm{SO}_{4}$. The cationic dominance pattern was similar to that of seawater but the anionic dominance pattern was a blend between those of the seawater and freshwater. A general downstream decrease in the river water concentrations was observed for the majority of determinands (Fig. 2). Correlation between mean values of selected determinands revealed expected process-based relationships, such as that between $\mathrm{Ca}^{2+}$ and $\mathrm{Mg}^{2+}(r=0.993 ; p<0.05)$ derived mainly from biogeochemical mineral weathering and that between $\mathrm{Na}^{2+}$ and $\mathrm{Cl}^{-}(r=0.998 ; p<0.05)$ derived mainly from atmospheric deposition. However, there were also many strong linear relationships between determinand species that are not normally expected to be linked in terms of processes. Examples of significant correla-tions between apparent unrelated species include those between $\mathrm{Ca}^{2+}$ and $\mathrm{Cl}^{-}(r=0.999 ; p$ $<0.05)$, between $\mathrm{Na}^{+}$and $\mathrm{NO}_{3}^{-}-\mathrm{N}(r=0.935)$ and between $\mathrm{K}^{+}$and $\mathrm{SO}_{4}^{2-}(r=0.858)$.

\section{Seasonal variation of chemical parameters}

There were seasonal changes associated with the conductivity and the general tendency was high values during the rainy season (May, June and July) and relatively lower values in the dry season (Fig. 3). This observation reflected in high TDS, chloride, sodium, potassium, sulphate and magnesium in the river water during the rainy season. These parameters varied for all the sites with the seasons and were generally high during the rainy season (Fig. 3). However, nutrients such as orthophosphate, nitrate-nitrogen and ammonia-nitrogen did not show any clear seasonal variation.

Conductivity values have a direct relationship with the concentration of TDS and major ions in water (Chapman, 1992). The elevated levels of the conductivity, TDS, chloride, sodium, potassium, sulphate and magnesium during the rainy season could be attributed largely to soil salts that were flushed into the river by run-off. High sodium and electrical conductivity levels were observed in soils in the study area. These were attributed to enrichment from ingressed seawater and deposition by salty water particles carried by the wind (FAO, 1988) judging from the basin's proximity to the Atlantic Ocean. According to Asiamah (1995), there are four possible sources of salts in the soils, ocean drift, underground water, deposition by wind and mineral weathering in the till.

The maximum conductivity value of $1,400 \mu \mathrm{S} / \mathrm{cm}$ occurred in May at the selected site (SS). There is currently no official guideline as to what is considered a safe level for conductivity. However, according to Chapman (1992), conductivity of most freshwaters range from 10-1000 $\mu \mathrm{S} / \mathrm{cm}$ but may exceed $1000 \mu \mathrm{S} / \mathrm{cm}$ especially in polluted waters, or those receiving large quantities of land run-off.

\section{Bacteriological water quality}

The results obtained for bacteriological analysis are shown in Fig. 4. The data collected indicated that the microbial water quality of the Angaw river was poor. Total and faecal pollution occurred at all sampling stations throughout the sampling period, rendering the water unsuitable for domestic use without treatment. However, the river is suitable for primary and secondary contacts such as swimming and fishing. The mean total coliform counts for the upstream, selected site and the downstream were $69.3 \pm 47.4 \mathrm{cfu} / 100 \mathrm{ml}, 92.5 \pm 71.7 \mathrm{cfu} / 100 \mathrm{ml}$, and $65.3 \pm 23.7$ cfu/100 ml, respectively. The mean faecal coliform counts were US $(33.3 \pm 30.0 \mathrm{cfu} / 100 \mathrm{ml}) ; \mathrm{SS}$ 
$(50.5 \pm 46.1 \mathrm{cfu} / 100 \mathrm{ml})$ and DS $(44.3 \pm 24.8 \mathrm{cfu} / 100 \mathrm{ml})$. These counts were far above $0 \mathrm{cfu} / 100$ $\mathrm{ml}$, which is the recommended limit for no risk (WHO, 1987). These results imply the water source poses a health risk to consumers. The presence of pathogenic organisms in the water could be attributed to human and animal wastes from the communities along the river.

Although the microbial pollution is high for River Angaw, thus rendering the water unfit for human consumption, it is low in comparison with those of the Kakum, Nakwa and Birim rivers as reported by Ampofo (1997). In the interpretation of microbial data, it is very important to note that microbial constituents have a strong non-conservative behaviour in water. The concentration of the amount entering the water could change independently through various processes such as growth, settling to the sediments, chemical reactions and decay (DWAF, 2000).

\section{Conclusion}

The results indicated that most of the physico-chemical quality parameters of River Angaw were within the WHO limits for drinking water and, therefore, may be suitable for domestic purposes. In contrast, however, the bacteriological quality of the water points, as suggested by the total and faecal coliform counts, exceeded the standard $(0 \mathrm{cfu} / 100 \mathrm{ml})$ for potable water. In general, the bacteriological quality of the water was unacceptable, and would pose a serious risk to consumers without treatment. The poor bacteriological quality was due to direct contamination by animal and human wastes.

The striking characteristic of River Angaw is its high ionic content which is reflected in high conductivity, total dissolved solids and sodium levels. Relatively higher levels of most physicochemical constituents occurred at the upstream while lower concentrations were observed downstream due to the influence of River Volta which has lower ionic content. Conductivity, TDS and most major ions varied seasonally with elevated levels in the rainy season. However, nutrient levels were low during the study period and did not give any clear seasonal variation. Even though the nutrient concen-trations were low, care must be taken by the inhabitants and the District Assembly to avoid eutrophication in the river since it is being abstracted and treated for water supply.

\section{Acknowledgement}

The authors thank CSIR-Water Research Institute for the facilities provided. The authors also thank Messrs Emmanuel Adu Ofori, Sampson Abu and Albert Essien of the CSIR-Water Research Institute, for their technical support.

\section{References}

Ampofo J. A. (1997). A Survey of Microbial Pollution of Rural Domestic Water Supply in Ghana. Int. J. envir. Hlth Res. 7: 121-130.

Ansa-Asare O. D. and Asante K. A. (2000). The Water Quality of Birim River in South-East Ghana. W. Afr. J. appl. Ecol. 1: 23-34.

Antwi L. A. K. and Ofori-Danson P. K. (1993). Limnology of a Tropical Reservoir (The Kpong Reservoir in Ghana). Trop. Ecol. 34: 75-87.

APHA (1998). Standard Methods for the Examination of Water and Wastewater, 20th edn. APHA, Washington, D.C.

Asiamah R. D. (1995). Soils of Ho-Keta Plains, Volta Region, Ghana. Memoir No. 10. Soil Research Institute. Advent Press, Osu, Ghana.

Chapman D. (1992). Water Quality Assessment; A guide to the use of biota, sediments and water in environmental monitoring. University Press, Cambridge, 585 pp.

Dallas H. F. and Day J. A. (1993). The Effect of Water Quality Variables on River and Ecosystem. Water Research Commission Report No. TT 61/93. South Africa.

Department of Water Affairs and Forestry (DWAF) (2000). National Microbial Water Quality Programme. First Report on the Identification and Prioritisation of Areas in South Africa with a Potentially High Health Risk Due to Faecally Polluted Surface water. Pretoria, South Africa. 
DFID (1999). A Simple Methodology for Water Quality Monitoring. (G. R. Pearce, Chaudhry and S. Ghulum, ed.) Department for International Development, Wallingford.

FAO (1988). Salt Affected Soils and their Management. FAO Soils Bull. 39. FAO, Rome, Italy. 131 pp.

Gibbs R. J. (1970). Mechanisms controlling world water chemistry. Science 170: 1088-1090.

Hesterberg D. (1998). Biogeochemical cycles and processes leading to changes in mobility of chemicals in soils. Agric. Ecosyst Environ. 67: 121-133.

Horne A. J. and Goldman C. R. (1995). Limnology. McGraw Hill. 576 pp.

Kelter P. B., Grudman J., Hage D.S., and Carr J. D. (1997). A Discussion of Water Pollution in the US and Mexico with High School Laboratory Activities for Analysis of Lead, Anthrazine and Nitrate. Chem. Educ. 74 (12): 14131418.

Kempster P. L., Van Vliet H. R. and Kuhn A. (1997). The Need for Guideline to Bridge the Gap between Ideal Drinking Water Quality and Quality which is Practicably Available and Acceptable. Water SA 23(2): 163-167.

Langmuir D. (1997). Aqueous Environ-mental Geochemistry. Prentice-Hall, USA.

Lester J. N. and Birkett J. W. (1999). Microbiology and Chemistry for Environmental Scientists and Engineers, 2nd edn. E \& FN Spon, New York.

Murray K., Du Preez M. and Van Ginkel C. (2000). National Eutrophication Monitoring Programme. Implementation Manual Draft. Water Research Commission, Pretoria, South Africa.

OECD (1982). Eutrophication of Waters: Monitoring, Assessment and Control. Technical Report. Organisation for Economic Cooperation Development, Paris, France.

Rast W. and Thornton J. A. (1996). Trends in Eutrophication Research and Control. Hydrol. Proc. 10: 295.

Verma B. L. and Srivastava R. N. (1990). Measurement of the Personal Cost of Illness due to some Major Waterrelated issues in an Indian Rural Population. Int. J. Epidemiol. 19: 169-176.

Water Research Institute (1999). Baseline Data and Monitoring of Pollution on Volta Lake and Kpong Headpond. WRI Technical Report Submitted to VRA, No. 556.55. Accra. 118 pp.

Webb B. W. and Walling D. E. (1992). Water Quality. II. Chemical Characteristics. In The Rivers Handbook, volume I. (P. Calow and G. E. Petts, ed.), pp. 73-100. Blackwell Scientific Publica-tions, Oxford, UK.

WHO (2004). www.who.int/water_sanitation-health/publications/facts2004/en/index.html.

WHO (1984). Guidelines for Drinking Water Quality. World Health Organisation, Geneva.

WHO (1987). Guidelines for Drinking Water, vol. 1. Recommendations. World Health Organisation. Geneva, Switzerland.

WHO (1993). Guidelines for Drinking Water Quality. World Health Organisation. Geneva, Switzerland. 